\title{
PERANAN PROGRAM PEKANBARU CERDAS DALAM MENINGKATKAN PRESTASI ASNAF ZAKAT DARI SISWA-SISWI KURANG MAMPU DI KECAMATAN MARPOYAN DAMAI
}

\author{
Mohammad Filbert Musnal ${ }^{1}$ \& Husni Thamrin ${ }^{2}$ \\ $1 \& 2$ Program Studi Ekonomi Syariah, Pascasarjana UIN Suska Riau \\ Email:muhammadfilbert@ rocketmail.co.id,husni2017husni@gmail.com
}

\begin{abstract}
ABSTRAK
Penelitian ini bersifat penelitian lapangan (Field Research) pada Badan Amil Zakat Nasional (BAZNAS) Kota Pekanbaru yang berlokasi di Jalan Jendral Sudirman No. 482, Komplek Masjid ArRahman Pekanbaru. Penelitian ini bertujuan untuk mengetahui bagaimana peranan program Pekanbaru Cerdas dalam meningkatkan prestasi asnaf zakat dari siswa-siswi kurang mampu di Kecamatan Marpoyan Damai. Pendekatan dalam penelitian ini adalah pendekatan kualitatif dengan populasi sebanyak 49 orang siswa-siswi yang terdiri dari SD, SMP, dan SMA ditambah 2 orang pegawai BAZNAS untuk memperkuat data. Adapun metode pengumpulan data melalui observasi, wawacara, angket serta dokumentasi. Sedangkan metode pemilihan sampel pada penelitian ini menggunakan teknik total sampling. Adapun hasil dari penelitian yang telah dilakukan, penulis mengambil kesimpulan bahwa Badan Amil Zakat Kota Pekanbaru sudah berperan aktif dalam menyalurkan dana zakat kepada salah satu golongan penerima zakat yaitu siswa-siswi kurang mampu di Kecamatan Marpoyan Damai. Bantuan dana zakat yang diberikan pun sangat bermanfaat sehingga para penerimanya merasa sangat terbantu dan memberikan apresiasi yang baik.
\end{abstract}

Kata Kunci : Pekanbaru Cerdas, Prestasi Asnaf, Zakat.

\begin{abstract}
This research is a field research (Field Research) at the National Zakat Board (BAZNAS) Pekanbaru City, which is located at Jendral Sudirman No. 482 Street, Ar-Rahman Mosque Complex Pekanbaru. This study aims to determine how the role of the smart Pekanbaru program in increasing the achievement of zakat asnaf of underprivileged students in Marpoyan Damai District. The approach in this study is a qualitative approach with a population of 49 students consisting of SD, SMP and SMA plus 2 BAZNAS employees to strengthen the data. The data collection method is through observation, interview, questionnaire and documentation. and the sample selection method in this study using total sampling technique. As for the results of the research that has been done, the authors conclude that the Pekanbaru City Amil Zakat Board has played an active role in distributing zakat funds to one of the groups of zakat recipients, namely underprivileged students in Marpoyan Damai District. The zakat fund assistance given is very useful so that the recipients feel very helpful and give good appreciation.
\end{abstract}

Keywords : Pekanbaru Smart, Asnaf Aachievements, Zakat. 


\section{PENDAHULUAN}

Kemiskinan yang menjadi permasalahan sebagian kehidupan manusia memang telah ada sejak dahulu kala. Kemiskinan bukanlah permasalahan yang menyangkut individu atau pribadi seseorang saja tetapi menyangkut semua aspek seperti masyarakat sekitar, daerah, maupun Negara bahkan dunia. Maka kemiskinan merupakan salah satu dari sekian banyak problematika yang harus segera diselesaikan bangsa ini. Menjadi suatu kepastian bahwasanya penanggulangan kemiskinan menjadi bahasan paling penting dalam perbaikan negara. Salah satu upaya yang bisa dilakukan untuk mengurangi kemiskinan yaitu dengan zakat.

Islam memiliki sistem bernama zakat sebagai solusi dalam pengentasan kemiskinan dan pemberdayaan ekonomi umat. Islam meletakkan kewajiban pada setiap orang yang memiliki harta melebihi kebutuhan hidup layak agar menunaikan zakat. Disamping itu, seorang muslim dianjurkan menginfaqkan sebagian hartanya untuk membantu fakir miskin, karib kerabat, anak yatim dan orang-orang yang membutuhkan di sekitarnya. Lebih dari itu, seorang muslim semestinya tergerak hatinya untuk memikirkan kemaslahatan agama dan umat Islam pada umumnya.

Sejarah peradaban Islam mencatat di masa Khulafaur Rasyidin hingga khilafah terakhir yang diwakili oleh Khilafah Utsmani, zakat menjadi sistem utama dalam mengentaskan kemiskinan dalam negeri. Baitul mal sebagai pengelola keuangan negara yang juga termasuk zakat didalamnya, dapat dikatakan berhasil mengambil perannya sebagai penjaga kestabilan ekonomi negara.

Potensi zakat sangat besar untuk diberdayakan dan dibagikan kepada kalangan masyarakat kecil miskin.
Berdasarkan pengkajian BAZNAS potensi zakat di Indonesia mencapai Rp. 230 triliun tiap tahunnya. Artinya, potensi zakat nilainya hampir $10 \%$ dari APBN. Namun baru Rp. 8 triliun (3,5 persen) yang terkumpul. Dengan besarnya potensi zakat Indonesia, penanganan kemiskinan dengan mendorong dari sektor zakat lebih baik dibandingkan dengan berhutang ke luar negeri. Oleh sebab itu kesadaran untuk membayar zakat dan membangun edukasi dan literasi tentang zakat harus terus disuarakan demi membangun tanah air.

Hafidhuddin (2002) menjelaskan bahwa pengelolaan zakat di Indonesia sudah dilakukan sejak awal Islam masuk dan berkembang, baik oleh individu maupun kelompok atau institusi tertentu. Namun demikian, mayoritas ulama di dunia dan di Indonesia sepakat bahwa sebaiknya dana zakat lebih baik jika dilakukan oleh pemerintah. Zakat yang tidak dikelola secara management skill yang baik tidak akan tepat sasaran, tidak efektif dan efisien. Diharapkan pengelolaan oleh lembaga formal dapat meningkatkan efektifitas pengumpulan dan pengalokasian dana zakat untuk mencapai sasaran yang ditargetkan.

Berdasarkan Undang Undang No. 23 tahun 2011 tentang pengelolaan zakat, pengelolaan zakat dilakukan oleh Badan Amil Zakat Nasional (BAZNAS) dan Lembaga zakat swasta (Lembaga Amil Zakat disingkat LAZ). Menurut UndangUndang tersebut, BAZNAZ diberi wewenang untuk mengelola dan mengkoordinasikan semua lembaga zakat. Sedangkan LAZ memiliki wewenang dalam hal-hal pengumpulan, distribusi, pengelolaan dan pertanggung jawaban zakat (Beik \& Arsyianti, 2016).

Zakat menurut etimologi berarti, berkah, bersih, berkembang dan baik. Dinamakan zakat karena dapat mengembangkan dan menjauhkan harta 
yang telah diambil zakatnya dari bahaya. Menurut Ibnu Taimiyah, hati dan harta orang yang membayar zakat tersebut menjadi suci dan bersih serta berkembang secara maknawi.

Sedangkan menurut istilah adalah sejumlah harta tertentu yang wajib dikeluarkan oleh orang yang beragama Islam dan diberikan kepada golongan yang berhak menerimanya menurut ketentuan yang telah ditetapkan oleh Islam. Oleh karena itu setiap orang yang telah memenuhi kriteria yang telah ditetapkan agama wajib membayar zakat.

Zakat tidak bisa digunakan untuk sembarangan kepentingan. Seperti sudah kita ketahui, bahwa tentang zakat sendiri dalam Al-Qur'an disebutkan secara ringkas, maka secara khusus pula AlQur'an telah memberikan perhatian dengan menerangkan kepada siapa zakat itu harus diberikan. Zakat dibatasi untuk kepentingan umat Islam. Zakat yang diberikan kepada umat Islam pun dibatasi kepada delapan asnaf (kelompok/golongan), yaitu fakir, miskin, budak, amil, orang yang berhutang, orang yang dalam perjalanan menuntut ilmu dan kehabisan bekal, orang yang baru masuk Islam yang hatinya masih lemah (mualaf), dan orang yang memperjuangkan agama Islam (Suprayitno, 2015).

\section{TINJAUAN PUSTAKA}

\section{Pengertian Peranan}

Peranan berasal dari kata "peran". Peran memiliki makna yaitu seperangkat tingkat diharapkan yang dimiliki oleh yang berkedudukan di masyarakat.

Menurut $\begin{gathered}\text { Soekanto } \\ \text { pengertian }\end{gathered}$
peranan
menjelaskan
merupakan aspek dinamis kedudukan
(status). Apabila seseorang melakukan
hak dan kewajibannya sesuai dengan
kedudukannya, dia menjalankan suatu
peranan. Perbedaan antara kedudukan dan
peranan adalah untuk kepentingan ilmu

pengetahuan. Keduanya tak dapat dipisahkan karena yang satu tergantung pada yang lain dan sebaliknya. Tak ada peranan tanpa kedudukan atau kedudukan tanpa peranan.

\section{Pengertian Zakat}

Zakat adalah salah satu pilar penting dalam ajaran Islam. Secara etimologis, zakat memiliki arti kata berkembang (an-namaa), mensucikan (atthaharatu) dan berkah (albarakatu). Sedangkan secara terminologis, zakat mempunyai arti mengeluarkan sebagian harta dengan persyaratan tertentu untuk diberikan kepada kelompok tertentu (mustahik) dengan persyaratan tertentu pula (Hafidhuddin, 2002). Menurut Darajat (1991) zakat berasal dari kata "zakka" yang berarti suci, berkah, tumbuh berkembang dan terpuji. Razak (1996) menambahkan zakat berasal dari kata "tazkiyah" yang artinya mensucikan.

Zakat diharapkan akan mendatangkan kesuburan dan tumbuhnya pahala dari amal ini. Juga diharapkan akan mensucikan jiwa-jiwa orang yang telah berzakat dan harta yang telah dizakati menjadi suci dari hal-hal yang mengotori dari segala sesuatu yang syubhat (Zulkifli, 2014).

Secara umum, fungsi zakat meliputi bidang moral, sosial, dan ekonomi. Dalam bidang moral, zakat mengikis ketamakan dan keserakahan seseorang, sedangkan dalam bidang sosial, zakat berfungsi mengentaskan kemiskinan dari masyarakat (Nurhayati, 2011). Di bidang ekonomi zakat berfungsi sebagai salah satu instrumen untuk mengentaskan kemiskinan, pemerataan kekayaan, dan mempersempit kesenjangan yang terjadi antara kelompok kaya dan miskin.

Dengan adanya berbagai implikasi moral, sosial dan ekonomi maka zakat dapat membentuk intregritas sosial yang kukuh serta memperkuat ketahanan ekonomi masyarakat (Huda, 2010). Zakat 
banyak sekali mengandung manfaat, antara lain sebagai berikut:

1. Bagi orang yang mengeluarkan zakat:

a. Sebagai rasa syukur kepada Allah SWT.

b. Diri akan menerima pencerahan nur ketuhanan sehingga ia dapat merasakan kenikmatan dan kebahagiaan yang hakiki.

c. Membersihkan diri dari sifat kikir, serta mendidik agar bersifat mulia dan pemurah atau dermawan.

d. Membersihkan harta dari kemungkinan-kemungkinan tercampur dengan harta yang haram.

2. Pada harta benda yang dizakatkan:

a. Harta benda yang dizakatkan akan terlepas dari kezaliman dan kerusakan orang lain.

b. Hadirnya keberkahan atas harta yang dimiliki. Dengan menzakatkan harta maka sebenarnya harta tersebut tidak semakin berkurang namun justru akan makin bertambah.

c. Menjadi unsur penting dalam mewujudkan keseimbangan dalam distribusi harta dan tanggung jawab individu dalam masyarakat.

d. Memudahkan penyaluran harta dari seseorang kepada orang lain sehingga harta tersebut mengalir dan tidak beredar hanya dikalangan tertentu saja (Basri, 2010).

3. Bagi penerima zakat:

a. Dapat memenuhi kebutuhan atau kewajibannya sebagaimana orang lain.

b. Dapat membantu dalam upaya memerangi kesulitan dan kemiskinan. c. Dapat memperteguh dan memperkuat iman bagi orangorang yang mualaf.

\section{Antara Zakat, Infak, Sedekah, Wakaf dan Hibah}

Kelima hal ini merupakan potensi umat yang dapat diberdayakan guna kesejahteraan dan kemajuan umat (Romdhoni, 2017). Sekilas kelima hal tersebut terlihat sama dan sulit untuk dibedakan. Berikut uraian secara ringkas masing-masing pengertiannya.

1. Zakat. Zakat adalah bagian dari harta yang wajib diberikan oleh setiap muslim yang memenuhi syarat kepada orang-orang tertentu dengan syarta tertentu pula. Segala sesuatu yang tumbuh dan berkembang wajib dizakati. Zakat dapat dibedakan menjadi dua. Yang pertama zakat mal dan kedua zakat fitrah. Zakat mal atau zakat harta adalah bagian dari harta kekayaan milik seseorang (termasuk juga badan hukum) yang wajib dikeluarkan jika sudah mencapai nishab (ukuran tertentu) dan sudah mencapai haul, untuk golongan tertentu dalam jumlah minimal tertentu pula. Kedua, zakat fitrah yaitu zakat yang dikeluarkan pada malam dan hari raya Idul Fitri oleh umat setiap umat muslim yang mempunyai kelebihan nafkah. Zakat fitrah ini adalah berupa kebutuhan atau makanan pokok sebanyak $2,5 \mathrm{~kg}$ atau 3,5 liter.

2. Infak. Infak adalah pengeluaran sukarela yang dilakukan seseorang setiap kali memperoleh rezeki, sebanyak yang dikehendakinya.

3. Sedekah. Sedekah yaitu pemberian sukarela yang dilakukan oleh seseorang kepada orang lain, terutama kepada orang-orang miskin, setiap kesempatan terbuka yang tidak ditentukan baik jenis, jumlah maupun waktunya. Sedekah dapat berupa 
material dan non material. Non material dapat berupa ilmu ataupun minimalnya senyum kepada orang lain.

4. Wakaf. Wakaf artinya menahan. Maksudnya menahan sesuatu benda yang kekal zatnya untuk diambil manfaatnya sesuai dengan ajaran Islam. Maka orang yang mewakafkan hartanya tidak lagi berhak atas barang atau benda yang diwakafkannya.

\section{Syarat-Syarat Wajib Mengeluarkan Zakat}

Ada beberapa ketentuan bagi umat Islam untuk diwajibkan membayar zakat diantaranya:

1. Islam. Zakat hanya diwajibkan bagi orang Islam saja. Bagi non Muslim tidak diwajibkan untuk berzakat.

2. Merdeka. Hamba sahaya tidak wajib mengeluarkan zakat kecuali zakat fitrah, dan zakat fitrah tersebut diwajibkan kepada tuannya untuk membayarnya.

3. Milik sepenuhnya. Harta yang akan dizakati oleh para muzakki harus merupakan milik sepenuhnya seorang yang beragama Islam dan harus meredeka. Bagi harta yang bekerjasama antara orang Islam dengan orang bukan Islam, maka hanya harta bagian orang Islam saja yang dikeluarkan zakatnya.

4. Cukup haul. Cukup haul adalah harta tersebut dimiliki genap setahun, selama 354 hari menurut kalender hijriah atau 365 hari menurut kalender masehi.

5. Cukup nisab. Nisab adalah nilai minimal sesuatu harta yang wajib dikeluarkan zakatnya. Kebanyakan standar zakat harta ( $\mathrm{mal}$ ) menggunakan nilai harga emas saat ini, jumlahnya sebanyak 85 gram. Nilai emas dijadikan ukuran nisab untuk menghitung zakat uang simpanan, emas, saham, perniagaan, pendapatan dan uang dana pensiun.

Mengenai zakat ini telah dijelaskan dalam Al-Qur'an. Allah SWT berfirman dalam surah At-Taubah ayat 103:

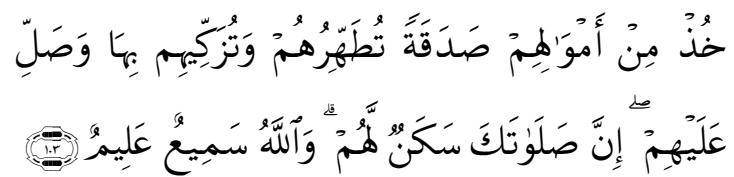

Artinya: "Ambillah zakat dari harta mereka, guna membersihkan dan menyucikan mereka, dan berdoalah untuk mereka. Sesungguhnya doamu itu (menumbuhkan) ketenteraman jiwa bagi mereka. Allah Maha Mendengar, Maha Mengetahui."'(Q.S. At-Taubah ayat 103)

\section{Badan Amil Zakat Nasional (BAZNAS)}

Badan Amil Zakat Nasional (BAZNAS) adalah lembaga pengelolaan zakat yang dibentuk oleh pemerintah yang anggota dan pengurusnya terdiri atas ulama, cendekiawan, profesional, tokoh masyarakat dan unsur pemerintah.

Berdasarkan Keputusan Presiden RI No. 8 Tahun 2001 BAZNAS merupakan badan resmi dan satu-satunya yang memiliki tugas dan fungsi menghimpun dan menyalurkan zakat, infaq, dan sedekah (ZIS) pada tingkat nasional. Lahirnya Undang-Undang Nomor 23 Tahun 2011 tentang pengelolaan zakat semakin mengukuhkan peran BAZNAS sebagai lembaga yang berwenang melakukan pengelolaan zakat secara nasional. Dalam UU tersebut, BAZNAS dinyatakan sebagai lembaga pemerintah nonstruktural yang bersifat mandiri dan bertanggung jawab kepada Presiden melalui Menteri Agama.

\section{Asnaf Zakat}

Adapun golongan yang menerima zakat terdiri dari delapan golongan yang disebut dengan asnaf zakat. Dalam QS. 
At-Taubah: 60 dijelaskan bahwa yang menjadi mustahiq zakat adalah fakir, miskin, amil, mualaf, riqab, gharim, fisabilillah, ibnu sabil.
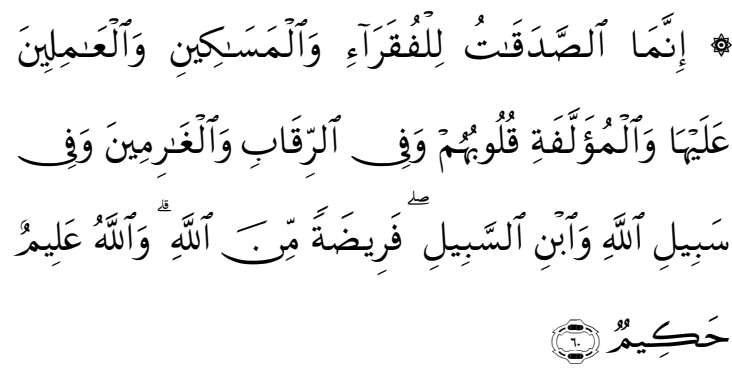

Artinya: "Sesungguhnya zakat itu hanyalah untuk orang-orang fakir, orang miskin, amil zakat, yang dilunakkan hatinya (mualaf), untuk (memerdekakan) hamba sahaya, untuk (membebaskan) orang yang berutang, untuk jalan Allah dan untuk orang yang sedang dalam perjalanan, sebagai kewajiban dari Allah. Allah Maha Mengetahui, Maha bijaksana." (Q.S. At Taubah ayat 60)

Mari kita lihat penjelasan tentang ayat diatas tentang pihak yang berhak menerima zakat, yakni (Chaniago, 2015):

1. Fakir - Menurut jumhur Ulama, yang disebut fakir adalah orang yang tidak mempunyai harta atau penghasilan banyak dalam memenuhi keperluannya. Sedangkan Hamka (1985) menjelaskan dalam Tafsir Al Azhar-nya menyatakan bahwa fakir adalah asal artinya "membungkuk tulang punggung", kemudian diambil maksud dari arti tersebut orang yang mengbungkuk tulang punggungnya karena memikul beban berat (hidup).

2. Miskin - Menurut jumhur Ulama, yang disebut miskin adalah mereka yang mempunyai harta atau penghasilan yang layak dalam memenuhi kebutuhannya dan orang yang menjadi tanggungannya, tetapi tidak sepenuhnya tercukupi. Menurut Hamka miskin dari kata sukuun yang artinya "berdiam diri" atau menahan penderitaan hidup. Maka tidaklah salah kalau ada yang berpendapat bahwa fakir dan miskin adalah satu jenis.

3. Amil - Mereka yang melaksanakan segala kegiatan urusan zakat, mulai dari para pengumpul sampai kepada bendahara dan para penjaganya. Demikian pula para pencatatnya sampai kepada penghitung yang mencatat keluar masuk zakat dan membagi kepada yang berhak. Allah SWT menyediakan upah bagi mereka dari harta zakat sebagai imbalan dan diambil dari harta zakat.

Untuk menjaga profesionalisme dari amil zakat maka diperlukan beberapa syarat yang harus dipenuhi:

a. Muslim

b. Seorang mukallaf yaitu orang dewasa yang sehat akal pikirannya

c. Jujur

d. Memahami hukum zakat

e. Memiliki kemampuan untuk melaksanakan tugas

f. Diutamakan laki-laki

g. Seorang yang merdeka bukan budak

4. Mualaf - Mereka yang baru masuk Islam dan membutuhkan bantuan untuk menyesuaikan diri dengan keadaan barunya.

5. Riqab - Hamba sahaya yang ingin memerdekakan dirinya. Jika masih ada di suatu negara sistem perbudakan maka zakat dapat digunakan untuk membebaskan seseorang dari perbudakan. Disamping itu suatu bangsa yang masih dalam penjajahan dapat menggunakan zakat untuk membebaskan diri dari penjajahan dari bangsa lain.

6. Gharim - Mereka yang berhutang untuk kebutuhan yang halal dan tidak sanggup untuk memenuhinya. Hamka 
(1985) menambahkan orang yang terdesak atau terlilit utang dapat mengajukan untuk mendapatkan zakat, sehingga utang tersebut dapat dibayar. Seseorang yang hendak berzakat pun dapat mengatakan terus terang kepada orang yang berhutang kepadanya, bahwa dia bersedia membayar zakatnya, asal dengan zakat itu hutangnya dibayarkan.

7. Fisabilillah - Mereka yang berjuang di jalan Allah SWT bukan hanya berperang saja melainkan segala sesuatu yang dilakukan untuk menegakkan agama Allah SWT sedangkan mereka tidak mendapatkan bayaran dari siapapun sedangkan untuk mencari nafkah untuk keluarganya sudah tidak ada lagi waktu dan tenaga.

8. Ibnu Sabil - Mereka yang kehabisan biaya di perjalanan bukan dalam rangka maksiat. Ibnu sabil menurut jumhur Ulama adalah kiasan dari musafir (orang yang dalam perjalanan) dan orang yang dalam perjalanan berhak mendapatkan zakat meskipun orang tersebut kaya. Mengapa musafir mendapatkan bagian dari zakat karena Islam sangat menganjurkan untuk bepergian dengan membaca ayat-ayat Allah SWT. Yang termasuk didalamnya adalah bepergian untuk mencari rezeki, untuk menuntut ilmu, untuk berjihad atau berperang di jalan Allah SWT dan perjalanan haji ke tanah suci.

\section{METODE PENELITIAN}

Jenis penelitian ini menggunakan pendekatan kualitatif yang berorientasi pada penelitian deskriptif kualitatif. Metode penelitian kualitatif berdasarkan pada pondasi penelitian, paradigma penelitian, perumusan masalah, tahaptahap penelitian, teknik penelitian, kriteria dan teknik pemeriksaan data dan analisis dan penafsiran data.
Metode analisis data dalam penelitian ini adalah metode deskriptif kualitatif. Jenis penelitian deskriptif kualitatif ini adalah jenis penelitian yang disusun dalam rangka memberikan gambaran secara sistematis tentang informasi ilmiah yang berasal dari subjek atau objek penelitian (Sanusi, 2011).

\section{Populasi}

Populasi adalah wilayah generalisasi yang terdiri atas: objek/subjek yang mempunyai kualitas dan karakteristik tertentu yang ditetapkan oleh peneliti untuk dipelajari dan kemudian ditarik kesimpulannya (Sugiyono, 2017).

Populasi dalam penelitian ini adalah asnaf zakat dari siswa-siswi kurang mampu yang terbagi menjadi 2 golongan yaitu Pekanbaru Cerdas Anak Asuh dan yang mendapatkan dana zakat hanya sekali saja di Kecamatan Marpoyan Damai yang berjumlah 49 orang.

\section{Sampel}

Sampel adalah kumpulan subjek yang mewakili populasi. Sampel yang diambil harus mempunyai karakeristik yang sama dengan populasinya dan harus mewakili (representative) anggota populasi (Chandrarin, 2017). Pengambilan sampel ini adalah dengan melakukan teknik total sampling.

\section{HASIL PENELITIAN DAN PEMBAHASAN}

Peranan Program Pekanbaru Cerdas terhadap Peningkatan Prestasi pada Asnaf Zakat dari Siswa-Siswi Kurang Mampu

Badan Amil Zakat Nasional (BAZNAS) Kota Pekanbaru ialah lembaga pemerintah non struktural yang bersifat mandiri, melakukan pengelolaan zakat di wilayah Kota Pekanbaru.

Keberadaan BAZNAS Kota Pekanbaru turut mendukung Program Pemerintah Kota Pekanbaru dalam 
mewujudkan Kota Pekanbaru sebagai Kota Smart City yang Madani.

Berdasarkan hasil penelitian penulis mendapatkan hasil berdasarkan wawancara kepada informan di BAZNAS sebagai berikut:

\section{Program BAZNAS}

$\begin{array}{llr}\text { Salah satu program } & \text { BAZNAS } \\ \text { Kota } \quad \text { Pekanbaru adalah program }\end{array}$ Pekanbaru Cerdas yang meliputi beberapa program seperti bantuan biaya pendidikan, beasiswa anak asuh BAZNAS dan paket tahun ajaran baru siswa-siswi yang tidak mampu. Terdapat dua pembagian dalam pemberian dana zakat kepada asnaf zakat, yaitu dana zakat yang diterima hanya sekali saja dan dana zakat yang diterima setiap bulannya yang disebut juga dengan anak asuh.

Pada kelompok yang hanya mendapatkan dana zakat hanya sekali mereka mendapatkan dana zakat yang cukup besar, namun mereka hanya akan mendapatkannya sekali saja atau tidak berkelanjutan. BAZNAS Kota Pekanbaru tidak sembarangan dalam menyalurkan dana zakat ini. Ada proses dan seleksi dalam pemberian yang dilakukan oleh BAZNAS seperti dengan mengisi formulir, mengikuti syarat dan ketentuan dari pihak BAZNAS.

\section{Adapun Alur Pelayanan Mustahik BAZNAS Kota Pekanbaru sebagai berikut:}

\section{Gambar 1. Alur Pelayanan Mustahik}

1. Mustahik datang ke BAZNAZ sesuai jadwal yang ditentukan

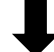

2. BAZNAS Pekanbaru mengeluarkan blanko untuk diisi mustahik sesuai dengan program yang dianjurkan

3. Membawa formulir

a. Mengisi formular yang telah diberikan oleh amil BAZNAS

b. Foto kopi KTP suami istri masing-masing 2 lembar

c. Foto kopi KK 2 lembar

d. Pas foto $3 \times 4$

e. Surat keterangan tidak mampu dari kelurahan yang diketahui oleh camat

f. Formulir (dari BAZNAS yang telah direkomendasikan oleh ketua masjid)

g. Surat keterangan dari sekolah

h. Foto kopi rapor terakhir

i. Formular (dari BAZNAS) yang telah direkomendasikan oleh sekolah

j. Pas foto orang tua dan anak masing-masing $3 \times 42$ lembar

4. Mustahik datang kembali untuk mengembalikan formulir sesuai jadwal kecamatan

Sumber: Data Olahan (2020) 


\section{Program Binaan oleh BAZNAS Kepada Penerima Zakat}

Program anak asuh pada BAZNAS ini disebut juga dengan program Pekanbaru Cerdas, yang dimana setiap bulannya siswa-siswi yang tergolong sebagai anak asuh mendapatkan dana zakat menerima porsi zakat sesuai dengan tingkatan sekolahnya seperti Sekolah Dasar mendapat dana zakat sebesar Rp. 150.000, Sekolah Menengah Pertama sebesar Rp. 200.000 dan Sekolah Menengah Atas sebesar Rp. 250.000, dimana setiap bulannya diadakan bimbingan untuk siswa-siswi yang menerima zakat sebagai anak asuh. Siswasiswi sebagai anak asuh akan diberikan bekal seperti dilatih dalam membaca AlQur'an. Hanya siswa-siswi kurang mampu yang dapat menerima beasiswa ini, artinya pihak BAZNAS benar-benar memilih, memilah dan melakukan survei langsung melihat seperti apa kehidupannya, apakah dia layak atau tidak dalam mendapatkan beasiswa ini.

\section{Kriteria Penerima Zakat dan Cara Penyaluran Dana}

Kriteria dalam mendapatkan dana zakat sebagai anak asuh dari BAZNAS adalah melihat dari segi perekonomian keluarganya, serta orang tuanya pun termasuk kedalam asnaf zakat. Penerima dana zakat yang diterima oleh siswa-siswi setiap bulannya dengan cara di transfer ke rekening BTN Syariah yang dibuatkan langsung oleh pihak BAZNAS agar mudah dalam penerimaannya.

Dalam rangka untuk melihat bagaiman peran Program Pekanbaru Cerdas, penulis mengadakan penelitian berupa angket yang disebarkan kepada 49 orang siswa-siswi yang menerima dana zakat dari Badan Amil Zakat Nasional (BAZNAS) Kota Pekanbaru yang akan dijadikan sebagai responden. Hasil jawaban dari responden penulis sajikan kedalam bentuk tabel seperti berikut:

a. Terkait dengan masa atau lama penerimaan dana zakat dari BAZNAS

Ada beberapa siswa-siswi yang mendapat dana zakat dengan jangka waktu yang cukup lama ataupun ada yang baru kali ini mendapatkannya dari pihak BAZNAS.

Tabel 1. Jangka Waktu Penerimaan Dana Zakat BAZNAS

\begin{tabular}{clcc}
\hline No & $\begin{array}{c}\text { Alternatif } \\
\text { Jawaban }\end{array}$ & Responden & Persentase \\
\hline 1 & Iya & 13 Orang & $26,53 \%$ \\
\hline 2 & Cukup & 29 Orang & $59,18 \%$ \\
\hline 3 & Tidak & 7 Orang & $14,29 \%$ \\
\hline & Jumlah & 49 Orang & $100 \%$ \\
\hline
\end{tabular}

Sumber: Data Olahan (2020)

Berdasarkan Tabel 1. dapat tahun) dalam penerimaan dana zakat diambil kesimpulan bahwa 13 orang atau $26,53 \%$ yang menjawab ia mendapatkan dana zakat telah lama (> 2 tahun), sedangkan 29 orang atau 59,18\% menjawab cukup lama dalam menerima dana zakat tersebut (1-2 tahun), dan 7 orang yang menjawab tidak lama $(<1$ tersebut.

b. Penerimaan dana zakat diterima setiap bulannya

Penulis juga menanyakan kepada responden terkait apakah siswa-siswi tersebut menerima dana zakat setiap bulannya, maka untuk mengetahui 
tanggapan dari responden dapat dilihat pada tabel 2:

Tabel 2. Penerimaan Dana Zakat Setiap Bulannya

\begin{tabular}{cccc}
\hline No & $\begin{array}{c}\text { Alternatif } \\
\text { Jawaban }\end{array}$ & Responden & Persentase \\
\hline 1 & Iya & 19 Orang & $38,77 \%$ \\
\hline 2 & Tidak & 30 Orang & $61,23 \%$ \\
\hline 3 & Tidak Pernah & - Orang & $0 \%$ \\
\hline & Jumlah & 49 Orang & $100 \%$ \\
\hline
\end{tabular}

Sumber: Data Olahan (2020)

Dari tabel diatas dapat diambil pengertian bahwa ada 19 orang atau $38,77 \%$ yang mendapat dana zakat dari BAZNAS setiap bulannya, sedangkan ada 30 orang menjawab tidak mendapatkan dana zakat setiap bulannya dan tidak ada satupun yang menjawa tidak pernah menerima dana zakat setiap bulannya.

Data ini diperkuat dengan wawancara dengan salah satu penerima zakat yang mengatakan bahwa dia mendapatkan dana zakat setiap bulannya sejumlah Rp. 150.000 untuk Sekolah
Dasar, Rp. 250.000 untuk Sekolah Menengah Pertama dan Rp. 250.000 untuk Sekolah Menengah Atas yang diterima setiap bulannya.

c. Bantuan dana yang diberikan mampu membantu biaya sekolah

Disamping itu juga ingin mengetahui tanggapan responden terkait dana zakat yang diterima apakah mampu membantu responden dalam memenuhi kebutuhan sekolahnya. Tanggapan responden dapat dilihat dari tabel berikut:

Tabel 3. Pengaruh Dana Zakat BAZNAS Terhadap Biaya Sekolah

\begin{tabular}{cccc}
\hline No & $\begin{array}{c}\text { Alternatif } \\
\text { Jawaban }\end{array}$ & Responden & Persentase \\
\hline 1 & Iya & 49 Orang & $100 \%$ \\
\hline 2 & Cukup & - Orang & $0 \%$ \\
\hline 3 & Tidak & - Orang & $0 \%$ \\
\hline & Jumlah & 49 Orang & $100 \%$ \\
\hline
\end{tabular}

Sumber: Data Olahan (2020)

Dari Tabel 3. dapat diambil kesimpulan bahwa sebanyak 49 orang atau $100 \%$ yang menjawab bahwa dengan adanya zakat mereka sangat terbantu dalam memenuhi biaya kebutuhan sekolah seperti halnya untuk membeli tas, sepatu atau alat tulis. d. Bantuan yang diberikan bermanfaat bermanfaat dan mampu membantu meringankan biaya sekolah mereka. Maka penulis ingin mengetahui bagaimana tanggapan mereka terhadap dana zakat yang diterima apakah bermanfaat bagi 
siswa-siswi yang menerimanya. tabel berikut:

Tanggapan responden dapat dilihat pada

Tabel 4. Manfaat Dana Zakat BAZNAS

\begin{tabular}{cccc}
\hline No & $\begin{array}{c}\text { Alternatif } \\
\text { Jawaban }\end{array}$ & Responden & Persentase \\
\hline 1 & Iya & 49 Orang & $100 \%$ \\
\hline 2 & Kurang & - Orang & $0 \%$ \\
\hline 3 & Tidak & - Orang & $0 \%$ \\
\hline & Jumlah & 49 Orang & $100 \%$ \\
\hline
\end{tabular}

Sumber: Data Olahan (2020)

Dari data diatas dapat disimpulkan bahwa seluruh responden yang berjumlah 49 orang setuju bahwa dana zakat yang mereka terima bermanfaat dan tidak ada satupun yang menjawab kurang bermanfaat atau tidak bermanfaat. Hal ini diperkuat dengan hasil wawancara dengan salah satu penerima dana zakat yang sangat terbantu dengan dana zakat yang diberikan oleh BAZNAS.

Tabel 5. Pengaruh Dana Zakat BAZNAS Terhadap Semangat Belajar

\begin{tabular}{cccc}
\hline No & $\begin{array}{c}\text { Alternatif } \\
\text { jawaban }\end{array}$ & Responden & Persentase \\
\hline 1 & Iya & 45 Orang & $91,83 \%$ \\
\hline 2 & Kurang & 4 Orang & $8,17 \%$ \\
\hline 3 & Tidak & - Orang & $0 \%$ \\
\hline & Jumlah & 49 Orang & $100 \%$ \\
\hline
\end{tabular}

Sumber: Data Olahan (2020)

Dari data diatas disimpulkan bahwa sebanyak 45 orang atau $91,83 \%$ menjawab bahwa dengan adanya dana zakat mereka merasa lebih semangat dalam belajar dan meningkatkan prestasi. Sedangkan ada 4 orang yang menjawab kurang giat dalam belajar dan tidak ada satupun yang menjawab bahwa ia tidak semangat dalam proses belajar mengajar. Hal ini diperkuat dengan hasil wawancara dengan beberapa siswa-siswi penerima dana zakat. Mereka mengatakan bahwa dengan adanya bantuan dana ini mereka e. Dana zakat yang diberikan menambah semangat dalam belajar

Terkait dengan dana yang diberikan BAZNAS kepada siswa-siswi ini, maka penulis ingin mengetahui apakah dana zakat yang diterima dapat menambah semangat siswa-siswi dalam belajar. Respon mereka dapat dilihat pada tabel di bawah ini : 
2021, Jurnal Tabarru' : Islamic Banking and Finance 4 (1) : 70 - 83

Tabel 6. Persyaratan Menerima Dana Zakat

\begin{tabular}{cccc}
\hline No & $\begin{array}{c}\text { Alternatif } \\
\text { jawaban }\end{array}$ & Responden & Persentase \\
\hline 1 & Iya & 49 Orang & $100 \%$ \\
\hline 2 & Tidak & - Orang & $0 \%$ \\
\hline 3 & Tidak Tahu & - Orang & $0 \%$ \\
\hline & Jumlah & 49 Orang & $100 \%$ \\
\hline
\end{tabular}

Sumber: Data Olahan (2020)

Dari data diatas dapat disimpulkan bahwa sebanyak 49 orang menjawab ada persyaratan dalam menerima dana zakat BAZNAS dan tidak satupun yang menjawab tidak dan tidak tahu. Persyaratan yang harus dipenuhi adalah berupa pengisian formulir, melampirkan fotocopy KTP dan KK serta persyaratan pendukung lainnya.
Adanya

bimbingan mendapatkan dana zakat yang dilakukan setiap bulannya

Terkait ada tidaknya bimbingan yang dilakukan pihak BAZNAS setiap bulannya. Respon dari responden dapat dilihat dari tabel berikut:

Tabel 7. Bimbingan Setelah Mendapatkan Dana Zakat

\begin{tabular}{cccc}
\hline No & $\begin{array}{c}\text { Alternatif } \\
\text { jawaban }\end{array}$ & Responden & Persentase \\
\hline 1 & Iya & 13 Orang & $26,53 \%$ \\
\hline 2 & Kurang Tahu & 29 Orang & $59,19 \%$ \\
\hline 3 & Tidak Tahu & 7 Orang & $14,28 \%$ \\
\hline & Jumlah & 49 Orang & $100 \%$
\end{tabular}

Sumber: Data Olahan (2020)

Dari data diatas bahwa sebanyak 13 orang atau $26,53 \%$ menjawab ada pembinaan dan sebanyak 29 orang menjawab kurang tahu sendangkan sebanyak 7 orang menjawab tidak tahu. Data diatas didukung dengan hasil wawancara dengan salah satu siswa yang mengatakan bahwa ia biasanya dibimbing dan diberi arahan serta dilatih membaca
Al-Qur'an dan lain sebagainya yang dilakukan sebulan sekali.

h. Apresiasi untuk BAZNAS dalam memberikan dana zakat

Terkait dengan kinerja BAZNAS dalam menyalurkan dana kepada siswasiswi yang mendapatkan dana zakat, tanggapan responden dapat dilihat pada tabel berikut : 
Tabel 8. Apresiasi Penerima Dana Zakat

\begin{tabular}{cccc}
\hline No & $\begin{array}{c}\text { Alternatif } \\
\text { Jawaban }\end{array}$ & Responden & Persentase \\
\hline 1 & Bagus & 8 Orang & $16,32 \%$ \\
\hline 2 & Sangat Bagus & 41 Orang & $83,68 \%$ \\
\hline 3 & Kurang Bagus & - Orang & $0 \%$ \\
\hline & Jumlah & 49 Orang & $100 \%$ \\
\hline
\end{tabular}

Sumber: Data Olahan (2020)

Dari data diatas dapat diambil kesimpulan bahwa ada sebanyak 8 orang atau $16,32 \%$ yang memberikan apresiasi bagus kepada pihak BAZNAS dan sebanyak 41 orang menjawab sangat bagus serta tidak satupun yang menjawab kurang bagus. Melalui wawancara data ini diperkuat salah satu responden yang mengatakan ia sangat senang sekali dengan adanya bantuan dana zakat dari BAZNAS dan merasa sangat terbantu dan diperhatikan pemerintah.

Faktor Yang Menghambat Atau Kendala Pada Program Pekanbaru Cerdas Dalam Meningkatkan Prestasi

Faktor-faktor yang menjadi penghambat pada program Pekanbaru Cerdas dalam meningkatkan prestasi siswa-siswi yang menerima zakat adalah kurangnya bekal bimbingan yang diberikan di bidang akademiknya, sehingga mereka kurang berprestasi dalam akademik. Kurangnya kesadaran bahwa pentingnya meningkatkan prestasi dan lebih giat dalam belajar karena sudah mendapatkan dana bantuan zakat dari BAZNAS pun menjadi salah satu kendala siswa-siswi dalam meningkatkan prestasi.

\section{KESIMPULAN}

Berdasarkan hasil analisis yang dilakukan, maka dapat diambil kesimpulan sebagai berikut : Pertama, dalam menyalurkan dana zakat, pihak
BAZNAS Kota Pekanbaru sudah berperan aktif dan baik dalam menyalurkan dana zakat kepada mustahik zakat yaitu dalam hal ini siswa-siswi kurang mampu di Kecamatan Marpoyan Damai. Bantuan yang diberikanpun dirasa sangat bermanfaat sehingga para penerimanya merasa sangat terbantu dan mendapat apresiasi yang baik. Kedua, Faktor-faktor yang menjadi penghambat pada program Pekanbaru Cerdas adalah kurang adanya bimbingan dalam penerimaan dana zakat tersebut sehingga mustahik zakat kurang berprestasi dalam bidang akademiknya. Kurangnya kesadaran bahwa pentingnya meningkatkan prestasi dan lebih giat dalam belajar karena sudah mendapatkan dana bantuan zakat dari BAZNAS pun menjadi salah satu kendala siswa-siswi dalam meningkatkan prestasi.

\section{DAFTAR PUSTAKA}

Basri, Helmi. 2010. Fiqih Ibadah (Panduan Ibadah Seorang Muslim). Suska Press. Pekanbaru.

Beik, I. S., \& Arsyianti, L. D. 2016. Measuring Zakat Impact on Poverty and Welfare Using CIBEST Model. Journal of Islamic Monetary Economics and Finance, 1(2), 141-160.

Chandrarin, G. 2017. Metode Riset Akuntansi Pendekatan Kuantitatif. Salemba Empat. Jakarta. 
Chaniago, S. A. 2015. Pemberdayaan Zakat Dalam Mengentaskan Kemiskinan. Jurnal Hukum Islam (JHI), 13(1), 47-56.

Darajat, Zakiah. 1991. Dasar-Dasar Agama Islam. Bulan Bintang. Jakarta.

Hafidhuddin, D. 2002. Zakat dalam Perekonomian Modern. Gema Insani Press. Jakarta.

Hamka. 1985. Tafsir Al Azhar Juzu'X. Pustaka Panjimas. Jakarta.

Huda, Nurul. 2010. Lembaga Keuangan Islam. Prenadamedia Group. Jakarta.

Nurhayati, Sri. 2011. Akuntansi Syariah di Indonesia. Salemba Empat. Jakarta.

Razak, Nasrudin. 1996. Dienul Islam. Al Ma'arif. Bandung.

Romdhoni, A. H. 2017. Zakat Dalam Mendorong Pertumbuhan Ekonomi dan Pengentasan Kemiskinan. Jurnal Ilmiah Ekonomi Islam, 3(1).

Sanusi, A. 2011. Metodologi Penelitian Bisnis. Salemba Empat. Jakarta.

Soekanto, S. 2002. Teori Peranan. Bumi Aksara. Jakarta.

Sugiyono. 2017. Metode Penelitian (Kuantitatif, Kualitatif, dan $R \& D$ ). Alfabeta. Bandung.

Suprayitno, Eko. 2015. Ekonomi Islam (Pendekatan ekonomi Makro Islam dan Konvensional). Penerbit Graha Ilmu, Yogyakarta.

Zulkifli. 2014. Panduan Praktis Pintar Memahami Zakat. Suska Press. Pekanbaru. 